\title{
ANALISIS KELAYAKAN ISI BUKU AJAR SAHABATKU INDONESIA dalam pembelajaran bipa
}

\author{
LINA HANDAYANI', SITI ISNANIAH² \\ Universitas Sebelas Maret \\ handayanilina4I@gmail.com',
}

Pertama Diterima: 8 Oktober 2019

Bukti Akhir Diterima: 29 Juni 2020

\begin{abstract}
Abstrak
Buku ajar merupakan salah satu komponen penunjang pembelajaran yang sangat penting keberadaannya. Baik dalam konteks pendidikan formal maupun non formal. Untuk itu pemilihan bahan ajar yang baik dan berkualitas dapat dilihat dari isi bahan ajar tersebut. Tujuan penelitian ini untuk mendeskripsikan kelayakan isi pada buku ajar Sahabatku Indonesia untuk Anak Sekolah B1. Metode penelitian dalam penelitian ini menggunakan metode deskriptif kualitatif dan kuantitatif. Hasil penelitian pada buku ajar Sahabatku Indonesia sudah layak digunakan dalam kegiatan belajar BIPA. Persentase kelayakannya pada buku ajar tersebut, pada bab pertama pertansenya kelayakannya sebesar $87,50 \%$, bab kedua persentasenya kelayakannya sebesar $77,50 \%$, bab tiga persentasenya kelayakannya sebesar $75,00 \%$, bab empat persentase kelayakannya sebesar 72,50\%, dan, pada bab lima persentase kelayaknnya sebesar 67,50\%. Jadi antara bab satu sampai bab limapersentase kelayakan dalam buku ajar tersebut semakin menurun. Berdasarkan persentase kelayakan lima bab buku tersebut kelayakan isi secara keseluruhan diperoleh 76,00\%. Hal tersebut mencakup, 1) Kesesuaian Standar Kompetensi dan Kompetensi Dasar meliputi tiga indikator yaitu, kelengkapan materi, keluasan materi dan, kedalaman materi. 2) Keakuratan materi terdapat tiga indikator yaitu, akurasi prosedur, akurasi soal dan, akurasi fakta, contoh, dan isi. 3) Materi pendukung pelajar terbagi menjadi empat indikator yaitu, keterkinian fitur, contoh, dan rujukan, penalaran, penerapan dan, kemenarikan materi.
\end{abstract}

Kata Kunci: kelayakan isi, Bahasa Indonesia bagi Penutur Asing , buku ajar

\begin{abstract}
Textbooks are one of the supporting components of learning which is very important. Both in the context of formal and non-formal education. For that the selection of good and quality teaching materials can be seen from the contents of the teaching material. The purpose of this study is to describe the feasibility of the contents of the teaching book My Indonesian Friends for School Children B1. The research method in this study uses descriptive qualitative and quantitative methods. The results of the research on teaching books My Friends of Indonesia have been worthy of being used in BIPA learning activities. The percentage of feasibility in the textbook, in the first chapter the feasibility session was $87.50 \%$, the second chapter of the feasibility percentage was $77.50 \%$, chapter three the percentage of feasibility was $75.00 \%$, chapter four the percentage of feasibility was $72.50 \%$, and, in chapter five the percentage is equal to $67.50 \%$. So between chapters one to five, the percentage of feasibility in the textbook decreases. Based on the percentage of the feasibility of the five chapters of the book, the overall content is obtained by 76.00\%. This includes, 1) Conformity of Competency Standards and Basic Competencies includes three indicators, namely, the completeness of the material, the breadth of material and, the depth of the material. 2) The accuracy of the material there are three indicators, namely, the accuracy of the procedure, the accuracy of the questions and, the accuracy of the facts, examples, and contents. 3) Student support material is divided into four indicators, namely, updating features, examples, and references, reasoning, application and material attractiveness.
\end{abstract}

Keywords: content feasibility, Indonesian for Foreign Speakers, textbooks 


\section{PENDAHULUAN}

Program Bahasa Indonesia bagi Penutur Asing (BIPA) diselenggarakan oleh dua lembaga yakni lembaga perguruan tinggi dan lembaga non perguruan tinggi (Khoirina et al, 2017). Lembaga perguruan tinggi meliputi mahasiswa-mahasiswa asing yang berkeinginan belajar Bahasa Indonesia serta menyelesaikan pendidikan formal mereka di Indonesia, sedangkan lembaga non perguruan tinggi biasanya digunakan untuk keperluan bisnis atau keperluan ekonomi lainnya seperti tenaga asing, atau para pemimpin perusahaan asing.

Pengajaran Bahasa Indonesia bagi Penutur Asing (BIPA) tidak dapat dipisahkan dengan adanya buku ajar yang memenuhi BSNP. Meskipun sampai sekarang di Indonesia belum ditetapkannya Kompetensi Dasar untuk BIPA, para pengajar BIPA disetiap lembaga pendidikan dapat mengacu kepada Common Europen Framework of Reference (CEFR). Alsan utama mengacu pada CEFR adalah CEFR dapat digunakan untuk pembelajaran bahasa asing di masyarakat multilingual di kawasan Asia Tenggara, Muliastutik (2017).

Firdaus, et al. (2014) menerangkan bahwa buku ajar merupakan salah satu buku penunjang pembelajaran pada sebuah sistem pendidikan. Buku ajar wajib digunakan pada sistem pendidikan formal maupun non formal. Materi yang terdapat di dalam sebuah buku ajar tidak hanya dapat mengembangkan ranah kognitif dan psikomotor pelajar akan tetapi juga memuat adanya ranah afektif.

Wardani (2017) mengelompokan menjadi dua yaitu buku ajar wajib dan buku ajar penunjang. Buku ajar wajib adalah buku ajar yang diterbitkan oleh Kementrian Pendidikan dan Kebudayaan yang telah melalui serangkain tahap kelayakan. Buku ajar penunjang adalah buku-buku pendamping buku pokok yang diterbitkan oleh instansi-instansi tertentu diluar Kemendikbud.

Di setiap buku ajar materi yang disajikan harus sesuai dengan Standar Kompetensi dan Kompetensi Dasar yang telah ditetapkan oleh Pemerintah. Kesesuaian ini meliputi kesesuaian materi dengan kurikulum, keruntutan materi, kedalaman materi, dan keluasan materi, Febriani (2018). Bukan hanya berkaitan dengan materi akan tetapi setiap buku ajar harus memerhatikan bahasa yang digunakan ke dalam buku ajar tersebut. Bahasa yang digunakan harus disesuaikan dengan jenjang pendidikan yang ditempuh. Tidak menggunakan bahasa yang terlalu sulit untuk dipahami dan tidak diperbolehkan menggunakan bahasa yang mudah dipahami.

Namun, isi materi yang terdapat di dalam setiap buku ajar belum tentu baik digunakan oleh pelajar BIPA. Hal tersebut dapat dilihat dari segi penyajian soal-soal latihan di dalam buku ajar tersebut. Banyak soal-soal latihan yang disajikan secara monoton. Artinya antara satu bab ke bab yang lain selalu terdapat soal latihan berupa uraian atau di dalam satu bab tersebut hanya terdapat soal latihan berupa uraian. Bentuk soal yang monoton seperti itulah yang kurang mengembangkan kemampuan kognitif dan psikomotorik pelajar BIPA. Maka dalam hal ini setiap buku ajar dalam penyajian soal-soal latihan haruslah divariasikan antara jenis soal objektif dan subjektif. Seperti diungkapkan oleh Asri (2017) buku teks Bahasa Indonesia yang bermutu akan meningkatkan kualitas dan hasil pembelajaran Bahasa Indonesia.

Pelajar BIPA merupakan mahasiswa/pekerja asing yang mempunyai latar belakang budaya dan bahasa yang berbeda. Pengaruh bahasa mempunyai konsekuensi dalam pemilihan materi ajar pada 
setiap lembaga penyelenggara BIPA, Suyitno (2007). Setiap buku ajar dari satu lembaga penerbit ke lembaga penerbit lain mempunyai kelemahan dan kelebihan masing-masing. Untuk menyesuaikan tingkat kebahasaan dan budaya para pelajar BIPA maka kelayakan isi pada buku ajar harus diperhatikan.

Muclish (2010) mengemukakan kelayakan isi pada buku ajar mempunyai 3 komponen penting diantaranya, kesesuaian uraian materi dengan Standar Kompetensi (SK) dan Kompetensi Dasar (KD) yang terdapat dalam kurikulum, keakuratan materi, serta materi pendukung pelajaran.Kesesuaian Standar Kompetensi dan Kompetensi Dasar meliputi tiga indikator yaitu, 1) kelengkapan materi, 2) keluasan materi dan, 3) kedalaman materi. Keakuratan materi terdapat tiga indikator yaitu, 1) akurasi prosedur, 2) akurasi soal dan, 3) akurasi fakta, contoh, dan isi. Materi pendukung pelajar terbagi menjadi empat indikator yaitu, 1) keterkinian fitur, contoh, dan rujukan, 2) penalaran, 3) penerapan dan, 4) kemenarikan materi.

Berkenaan dengan pentingnya penggunaan buku ajar dikalangan pelajar BIPA. Maka timbul pertanyaan standar buku ajar yang baik digunakan oleh para pelajar BIPA tingkat B1 berdasarkan isi.

\section{METODE PENELITIAN}

Metode penelitian dalam penelitian ini menggunakan metode deskriptif kualitatif dan kuantitatif. Menurut Aminudin (1995), metode deskriptif kualitatif adalah metode penelitian yang berbentuk pemaparan atau penggambaran kata-kata, bukan berbentuk angka atau numerik. Menurut Sugiyono (2017) metode kuantitatif adalah metode penelitian yang digunakan dalam meneliti sebuah sampel atau populasi tertentu.

Data dalam penelitian berupa kata, frasa, kalimat, pada buku ajar mengenai kajian isi. Sumber data dalam penelitian ini ada dua yaitu sumber primer dan sumber sekunder. Sumber primer yaitu buku Sahabat Indonesia untuk Anak Sekolah B1, sedangkan sumber sekunder yaitu buku, artikel jurnal, proseding, yang berkaitan dengan analisis kelayakan isi.

Teknik pengumpulan data dalam penelitian ini menggunakan teknik baca catat. Teknik analisis data dalam penelitian ini menggunakan teknik deksripsit. Menurut Ratna (2013) teknik analisis deskriptif yaitu teknik analisis dengan jalan menjelaskan suatu permasalahan, faktor atau penyebab, bukan menguji hipotesis.

\section{HASIL DAN PEMBAHASAN}

\section{Gambaran Umum buku Sahabat Indonesia untuk Anak Sekolah B1 Penerbit Kemendikbud}

Buku ajar BIPA tingkat B1 (BIPA 3) dalam setiap babnya terdiri dari beberapa bagian. Pertama, terdapat kover, daftar isi materi, serta peta konsep materi yang akan diajarkan pada tingkat BIPA 3. Kedua, kolom Hobidimana pada tema hobi dibagi menjadi dua bab. Pada bab yang pertama lebih mendeskripsikan tentang hobi dimana dalam bab tersebut berisi bacaan sederhana tentang hobi seperti, "Mendaki Gunung" dimana dalam bacaan tersebut para pelajar BIPA diajarkan toleransi sesama makhluk hidup. Hobi pada bab selanjutnya berkaitan dengan kebiasaan masyarakat 
Indonesia pada umumnya serta cara melakukan aktivitas tersebut seperti "Ngurek" yang di dalamnya berisi langkah-langkah melakukan Ngurek. Ketiga, Tempat Wisatayang membicarakan tentang "Danau Kelimutu" dimana bacaan tersebut lebih kepada mendeskripsikan tempat serta makna warna air dalam danau tersebut. Keempat, Kegiatan Wisatadalam hal ini tema yang dibicarakan "Berlibur ke Bogor" di dalam bacaan tersebut penulis menceritakan kegiatan awal keberangkatan sampai kembali ke rumah. Kelima, Legenda Tempat Wisata dalam bab ini berisi tentang sejarah terjadinya sebuah tempat wisata salah satunya "Legenda Situ Patenggang". Setiap bab dan tema yang diambil pada buku Sahabat Indonesia selalu diberikan berbagai ilustrasi dan kosa kata yang harus dikuasai yang berkaitan dengan tema tersebut. Selain itu, dalam setiap bab dengan tema yang sama diberikan empat aspek kebahasaan yaitu berbicara, membaca, menulis, dan menyimak. Pada aspek menyimak, pelajar BIPA diberikan ilustrasi gambar serta diputarkan audio berkaitan dengan tema bab tersebut. Aspek membaca pelajar BIPA diberikan bacaan singkat tentang tema yang berkaitan dengan bab tersebut. Kegiatan berbicara, pelajar BIPA diberikan teks percakapan yang berkaitan dengan tema bab tersebut. Selanjutnya kegiatan menulis di buku ajar ini terdapat dua kategori dalam menulis. Kegiatan menulis pertama pelajar BIPA melakukan kegiatan menulis berupa merangkum bacaan yang telah ia baca, kedua pelajar BIPA menulis pengalaman berkaitan tentang tema yang ada bab tersebut. Untuk latihan yang diberikan berbentuk subjektif dan objektif. Pada subjektif terdiri dari uraian, dan kalimat rumpang, sedangkan dalambentuk objektif berupa pilihan ganda, serta penjodohan antara pertanyaan dan jawaban. Di akhir setiap bab selalu diberikan wawasan lain tentang Indonesia berkaitan dengan tema pada bab tersebut.

\section{Kelayakan Isi Buku Ajar Sahabat Indonesia untuk Anak Sekolah B1 (BIPA 3)}

Beracuan pada kelayakan isi BSNP dalam analisis buku ajar Sahabat Indonesia untuk Anak Sekolah B1, telah ditemukan hasil analisis sebagai berikut.

Tabel 1. Analisis Kelayakan Isi Bab 1

\begin{tabular}{|c|c|c|c|c|c|}
\hline \multicolumn{6}{|l|}{ Bab 1. Hobi } \\
\hline \multirow{2}{*}{ Komponen } & \multirow{2}{*}{ Indikator } & \multicolumn{4}{|c|}{ Skor } \\
\hline & & 1 & 2 & 3 & 4 \\
\hline \multirow{3}{*}{$\begin{array}{l}\text { Kesesuaian materi } \\
\text { dengan } \mathrm{KD}\end{array}$} & Kelengkapan Materi & & & & $\sqrt{ }$ \\
\hline & Keluasan Materi & & & $\sqrt{ }$ & \\
\hline & Kedalaman Materi & & & & $\sqrt{ }$ \\
\hline \multirow{3}{*}{ 2. Keakuratan Materi } & Akurasi prosedur & & & $\sqrt{ }$ & \\
\hline & Akurasi fakta, contoh, dan isi & & & & $\sqrt{ }$ \\
\hline & Akurasi Soal & & & & $\sqrt{ }$ \\
\hline \multirow{4}{*}{$\begin{array}{l}\text { 3. Materi Pendukung } \\
\text { Pelajaran }\end{array}$} & Keterkinian fitur, contoh, dan rujukan & & & & $\sqrt{ }$ \\
\hline & Penalaran & & & $\sqrt{ }$ & \\
\hline & Penerapan & & & $\sqrt{ }$ & \\
\hline & Kemenarikan Materi & & & $\sqrt{ }$ & \\
\hline \multicolumn{2}{|l|}{ Jumlah } & \multicolumn{4}{|c|}{35} \\
\hline \multicolumn{6}{|c|}{ Jumlah Skor Maksimal=40 } \\
\hline \multicolumn{2}{|c|}{ Persentase Kelayakan $(35 / 40) * 100 \%=87,50 \%$} & & & & \\
\hline
\end{tabular}


Pada analisis bab 1 kelengkapan materi sudah sesuai dengan KD yang telah ditetapkan oleh Kemendikbud yaitu tentang teks deskripsi. Keluasan materi dalam buku tersebut cukup luas, meskipun hanya terdapat satu contoh bacaan yang dianalisis dengan materi. Kedalaman materi dalam buku ajar tersebut sudah baik, dan terfokus pada apa yang dibicarakan yaitu tentang tema Hobi. Keakuratan materi sudah baik, dengan diberikannya banyak bacaan seperti "Mendaki Gunung", dan "Menulis". Keakuratan prosedur sudah sistematis yaitu perintah yang diberikan jelas dan terarah seperti pada halaman 6 pada aspek membaca. Materi pendukung pembelajaran, refensi yang diambil sangat mutahir yakni tidak lebih dari 5 tahun. Pada indikator penalaran sudah baik, yaitu menyimpulkan bacaan yang telah di baca sebelumnya dari satu paragraf ke paragraf selanjutnya seperti pada halaman 8. Penerapan dan kemenarikan materi sudah baik, dengan didukung tabel sehingga memudahkan para pelajar BIPA untuk memahaminya dibandingan hanya dengan disajikan dalam bentuk uraian.

Tabel 2. Analisis Isi Kelayakan Bab 2

\begin{tabular}{|c|c|c|c|c|c|c|}
\hline \multicolumn{7}{|c|}{ Bab 2. Hobi } \\
\hline \multirow{2}{*}{\multicolumn{2}{|c|}{ Komponen }} & \multirow{2}{*}{ Indikator } & \multicolumn{4}{|c|}{ Skor } \\
\hline & & & 1 & 2 & 3 & 4 \\
\hline \multirow{3}{*}{\multicolumn{2}{|c|}{$\begin{array}{ll}\text { 1. } & \text { Kesesuaian materi } \\
\text { dengan } \mathrm{KD}\end{array}$}} & Kelengkapan Materi & & & & $\sqrt{ }$ \\
\hline & & Keluasan Materi & & $\sqrt{ }$ & & \\
\hline & & Kedalaman Materi & & $\sqrt{ }$ & & \\
\hline \multirow{3}{*}{\multicolumn{2}{|c|}{ 2. $\quad$ Keakuratan Materi }} & Akurasi prosedur & & & $\sqrt{ }$ & \\
\hline & & Akurasi fakta, contoh, dan isi & & & $\sqrt{ }$ & \\
\hline & & Akurasi Soal & & & & $\sqrt{ }$ \\
\hline \multirow{4}{*}{\multicolumn{2}{|c|}{$\begin{array}{l}\text { 3. } \\
\text { Pateri Pendukuaran } \\
\text { Pelajung }\end{array}$}} & Keterkinian fitur, contoh, dan rujukan & & & & $\sqrt{ }$ \\
\hline & & Penalaran & & & $\sqrt{ }$ & \\
\hline & & Penerapan & & & $\sqrt{ }$ & \\
\hline & & Kemenarikan Materi & & & $\sqrt{ }$ & \\
\hline \multicolumn{3}{|c|}{ Jumlah } & \multicolumn{4}{|c|}{31} \\
\hline \multicolumn{7}{|c|}{ Jumlah Skor Maksimal $=40$} \\
\hline \multicolumn{3}{|c|}{ Persentase Kelayakan $(31 / 40) * 100 \%=77,50 \%$} & & & & \\
\hline
\end{tabular}

Berdasarkan analisis pada bab 2, maka kesesuaian materi secara keseluruhan sudah sesuai dengan Kompetensi Dasar yaitu menulis teks deskriptif prosedur. Indikator kelengkapan materi sudah sangat baik, yaitu semua indikator dalam Kompetensi Dasar di bab 2 sudah ada dalam materi tersebut. Pada keluasan materi, masih kurang baik, karena di dalam bab 2 ada satu bacaan yang mempunyai topik yang dan judul yang sama dengan bacaan bab 1 perbedaannya pada bab 1 bacaan tersebut terdapat pada kompetensi menyimak sedangkan pada bab 2 bacaan tersebut berada pada kompetensi membaca. Kedalaman materi juga masih perlu ditingkatkan, dalam hal analisis struktur organisasi yang membangun teks tersebut. Pada komponen keakurtan materi secara keseluruhan keakurtannya sudah baik. Hal tersebut dapat dilihat pada akurasi prosedur dimana pada bab 2 disajikan dengan runtut orgnanisasi teks deskripsi prosedur seperti pada halaman 37. Akurasi fakta, contoh, dan isi, sudah baik bisa lihat pada bacaan "Ngurek" dimana dalambacaan tersebut fakta, contoh, dan isi sudah menggambarkan keadaan sebenarnya kegiatan Ngurek tersebut. Akurasi soal, berbeda halnya pada bab 1, bab 2 soal-soal yang diberikan lebih bervariasi yaitu terdapat soal 
pilihan ganda, uraian, serta kegiatan menulis pengalam pribadi. Komponen terakhir yaitu pada materi pendukung pelajaran secara keseluruhan materi pendukung tersebut sudah baik, terutama pada indikator keterkinian fitur, contoh, dan rujukan, dimana dalam hal ini penulis menyajikan lebih banyak gambar ilustrasi beraneka ragam mulai dari gambar makanan, gambar serta lat-alat perlengkapan yang berkaitan dengan memancing. Pada indikator penalaran dan penerapan sudah baik dengan membuat pelajar BIPA menuliskan hobi mereka yang dituangkan ke dalam teks deskripsi prosedur. Indikator yang terakhir yaitu kemenarikan materi, dalam hal ini materi yang ditampilkan menarik. Selain para pelajar mengetahui keaneragaman aktivitas pada masyarakat Indonesia mereka juga bisa mempraktekan apa yang telah mereka ketahui melalui teks deskripsi prosedur yang telah mereka baca.

Tabel 3. Analisis Kelayakan Isi Bab 3

\begin{tabular}{|c|c|c|c|c|c|}
\hline \multirow{2}{*}{ Komponen } & \multirow{2}{*}{ Indikator } & \multicolumn{4}{|c|}{ Skor } \\
\hline & & 1 & 2 & 3 & 4 \\
\hline \multirow{3}{*}{$\begin{array}{l}\text { 1. } \begin{array}{l}\text { Kesesuaian materi } \\
\text { dengan KD }\end{array}\end{array}$} & Kelengkapan Materi & & & & $\sqrt{ }$ \\
\hline & Keluasan Materi & & & $\sqrt{ }$ & \\
\hline & Kedalaman Materi & & & $\sqrt{ }$ & \\
\hline \multirow[t]{3}{*}{ 2. $\quad$ Keakuratan Materi } & Akurasi prosedur & & & $\sqrt{ }$ & \\
\hline & Akurasi fakta, contoh, dan isi & & & $\sqrt{ }$ & \\
\hline & Akurasi Soal & & $\sqrt{ }$ & & \\
\hline \multirow{4}{*}{$\begin{array}{ll}\text { 3. } & \text { Materi Pendukung } \\
\text { Pelajaran }\end{array}$} & Keterkinian fitur, contoh, dan rujukan & & $\sqrt{ }$ & & \\
\hline & Penalaran & & & $\sqrt{ }$ & \\
\hline & Penerapan & & & $\sqrt{1}$ & \\
\hline & Kemenarikan Materi & & & & $\sqrt{ }$ \\
\hline \multicolumn{2}{|l|}{ Jumlah } & \multicolumn{4}{|c|}{30} \\
\hline \multicolumn{6}{|c|}{ Jumlah Skor Maksimal $=40$} \\
\hline \multicolumn{2}{|c|}{ Persentase Kelayakan $(30 / 40) * 100 \%=75,00 \%$} & & & & \\
\hline
\end{tabular}

Pertama, kesesuaian materi dengan KD sudah sesuai yaitu tentang teks deksripsi dengan topik tempat wisata. Selanjutnya, pada indikator kelengkapan materi,materi yang disajikan pada buku ajar B1 sangat lengkap dengan dihadirkan berbagai macam topik kebudayaan terutama tempat wisata yang ada di Indonesia seperti pada halaman 55. Keluasan materi sudah baik, artinya tidak melulu hanya dua atau tiga topik akan tetapin lebih banyak topik yang diberikan. Kedalaman materi pada bab 3 sudah baik, dengan diberikan analisis organisasi teks deksripsi beserta dengan contohnya. Kedua, keakuratan materi, pada indikator akurasi prosedur dan akurasi fakta, contoh, dan isi, sudah baik dengan memberikan sejarah kebudayaan tempat wisata yang ada di Indonesia dengan menggunakan rujukan yang dipercaya. Pada indikator akurasi soal, masih sangat miskin variasi soal yang diberikan. Pada bab ini yang disajikan hanya bentuk soal uraian. Ketiga, materi pendukung pelajaran, indikator keterkinian fitur, contoh, dan rujukan, masih kurang aktual, dapat dilihat pada bacaan “ Masjid Agung Demak” dimana rujukan yang dipakai Wikipedia, meskipun keakuratan dalam bacaan tersebut sudah baik akan tetapi referensi yang digunakan minimal harus 5 tahun. Indikator penalaran dan penerapan, seperti pada bab-bab sebelumnya pada indikator ini ditampilkan dengan baik yaitu pada kegiatan ini pelajar BIPA dituntut untuk menggunakan semaksimal 
mungkin daya penalaran dalam mendeskripsikan tempat wisata yang pernah mereka kunjungi. Pada indikator terakhir ini, materi yang ditampilkan sangat menarik bagi pelajar BIPA, selain materi yang diberikan tidak membosankan, mereka juga bisa menambahkankan pengetahuan mereka tentang tempat-tempat wisata yang ada di Indonesia.

Tabel 4. Analisis Kelayakan Isi Bab 4

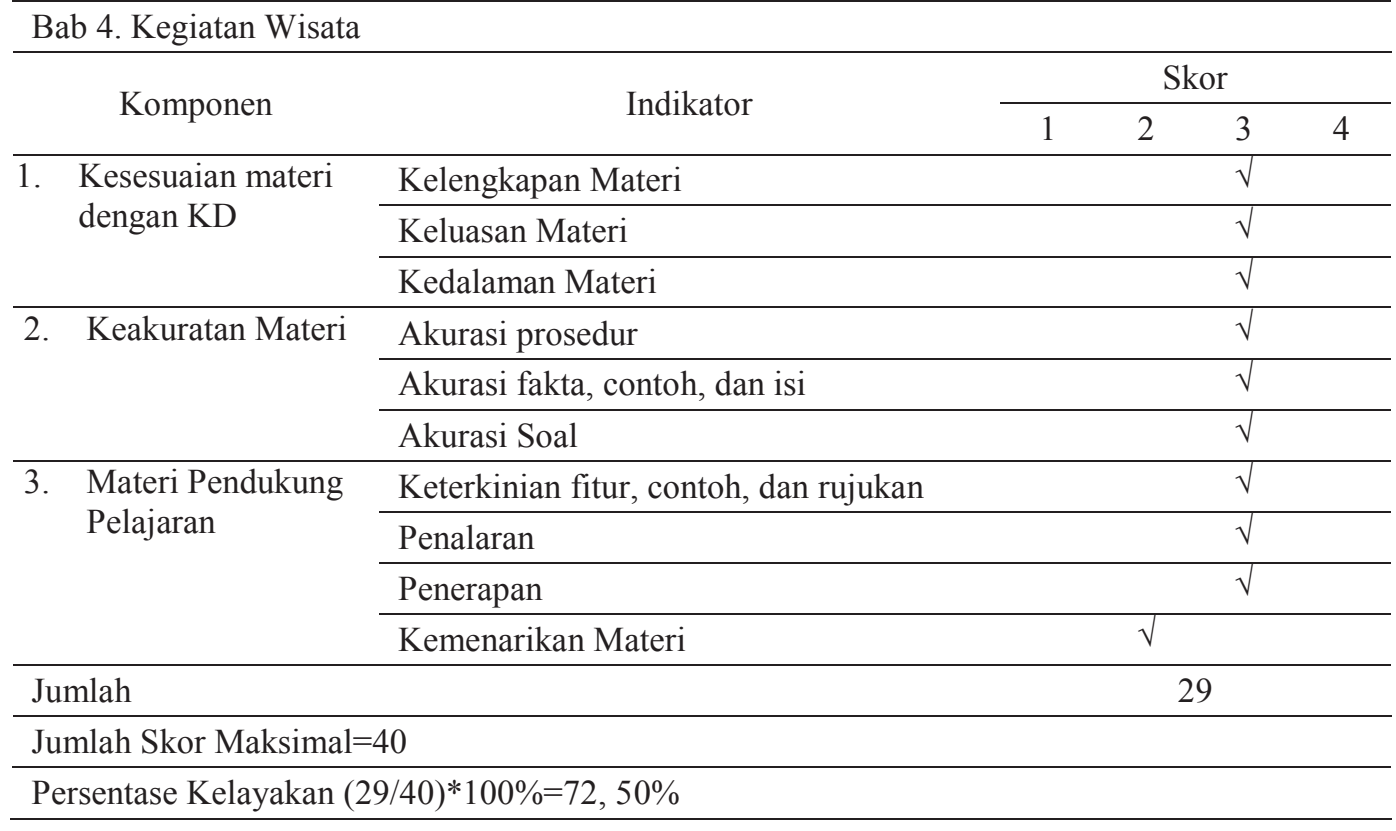

Analisis kelayakan isi pada bab 4, 1) komponen kesesuaian materi dengan KD sudah sesuai yaitu pada bab ini membicarakan teks rekon dengan tema kegiatan wisata. Indikator pertam kelengkapan materi,materi yang terdapat dalam buku ajar Sahabat Indonesia sudah baik, yaitu terdapat empat aspek kebahasaan menyimak, membaca, menulis, dan berbicara. Indikator kedua keluasan materi, materi yang disajikan dalam buku ajar tersebut sudah baik yaitu mencakup beberapa bentuk bacaan yang berkaitan dengan teks rekon. Indikator yang ketiga kedalaman materi, kedalaman materi ini dapat dilihat dari penyajian bacaan yang mencakup 3 komponen organisasi struktur teks yang meliputi orientasi,peristiwa, reorientasi. 2) keakurtan materi, indikator pertama akurasi prosedur sudah baik dengan penyajian teks tersebut disajikan bacaan yang awalnya mudah semakin tinggi tingkat aspek kebahasaan maka semakin sulit. Indikator kedua, akurasi fakta, contoh, dan isi, pada bacaan pertama berjudul Berlibur ke Bogor dalam bacaan tersebut mengenalkan budaya Jawa berupa Gong kepada para pelajar BIPA. Bacaan kedua berjudul Jalanjalan di Kampung Sampireu, pelajar BIPA diajak untuk mengenal tempat wisata yang ada di Indonesia dengan beraneka ragam tempat serta mempunyai keunikan masing-masing. Indikator ketiga akurasi soal, soal yang terdapat dalam buku ajar tersebut berbentuk uraian dengan jenis uraian singkat, kalimat rumpang, serta menulis kembali. 3) meteri pendukung pelajaran, indikator pertama contoh yang diberikan sudah terbaru dengan pemilihan ilustrasi yang sesuai dengan tema yang diberikan. Indikator selanjutnya, penalaran dan penerapan sudah baik dengan diadakannya penuangan ide pengalaman kegiatan wisata kepada para pelajar BIPA. Indikator terakhir kemenarikan materi, penyajian materi diberikan cukup baik diberikan uraian dan gambar. 
Tabel 5. Analisis Kelayakan Isi Bab 5

\begin{tabular}{|c|c|c|c|c|c|}
\hline \multicolumn{6}{|c|}{ Bab 5. Legenda Tempat Wisata } \\
\hline \multirow[t]{2}{*}{ Komponen } & \multirow[t]{2}{*}{ Indikator } & \multicolumn{4}{|c|}{ Skor } \\
\hline & & 1 & 2 & 3 & 4 \\
\hline \multirow{3}{*}{$\begin{array}{ll}\text { 1. } & \text { Kesesuaian } \\
\text { materi } \\
\text { dengan } \mathrm{KD}\end{array}$} & Kelengkapan Materi & \multicolumn{4}{|c|}{$\sqrt{ }$} \\
\hline & Keluasan Materi & \multicolumn{4}{|c|}{$\sqrt{ }$} \\
\hline & Kedalaman Materi & \multicolumn{4}{|c|}{$\sqrt{ }$} \\
\hline \multirow{3}{*}{$\begin{array}{l}\text { 2. Keakuratan } \\
\text { Materi }\end{array}$} & Akurasi prosedur & \multicolumn{4}{|c|}{$\sqrt{ }$} \\
\hline & Akurasi fakta, contoh, dan isi & \multicolumn{4}{|c|}{$\sqrt{ }$} \\
\hline & Akurasi Soal & \multicolumn{4}{|c|}{$\sqrt{ }$} \\
\hline \multirow{4}{*}{$\begin{array}{ll}\text { 3. } & \text { Materi } \\
\text { Pendukung } \\
\text { Pelajaran }\end{array}$} & $\begin{array}{l}\text { Keterkinian fitur, contoh, dan } \\
\text { rujukan }\end{array}$ & & & & $\sqrt{ }$ \\
\hline & Penalaran & \multicolumn{4}{|c|}{$\sqrt{ }$} \\
\hline & Penerapan & \multicolumn{4}{|c|}{$\sqrt{ }$} \\
\hline & Kemenarikan Materi & & & & $\sqrt{ }$ \\
\hline Jumlah & & \multicolumn{4}{|c|}{27} \\
\hline \multicolumn{6}{|c|}{ Jumlah Skor Maksimal=40 } \\
\hline Persentase Kelas & an $(27 / 40) * 100 \%=67,50 \%$ & & & & \\
\hline
\end{tabular}

Kelengkapan materi sudah sesuai dengan Kompetensi Dasar yang telah ditetapkan yaitu berkaitan dengan teks narasi. Keluasan materi yang terdapat dalam buku ajar tersebut cukup baik sudah terdapat contoh akan tertapi belum terdapat konsep serta definisi ndari materi yang hendak disampaikan. Kedalaman materi yang disajikan sudah baik, dengan diberikannya contoh sesuai dengan KD maka akan mengembangkan afektif, kognitif dan psikomotorik pelajar BIPA. Akurasi prosedur dalam bab ini sudah jelas, baik bacaan ataupun soal sudah diberikan prosedur secara sistematis sehingga pelajar BIPA tidak akan keliru dalam mengerjakan perintah yang diberikan pengajar. Akurasi fakta, contoh, dan isi, ketiganya sudah terdapat dalam buku ajar Sahabat Indonesia seperti pada bacaan Legenda Candi Prambanan yang pada kenyatannya fakta tenang candi prambanan memang ada tepatnya di Daerah Istimewa Yogyakarta. Akurasi soal dalam bab 5 jenis subjektif dengan satu bentuk yaitu uraian, baik uraian singkat ataupun panjang. Keterkinian fitur, contoh, dan rujukan, sudah baik yaitu dengan menggunakan rujukan tahun 2015 sedangkan pembuatan buku ini pada tahun 2016 maka dapat dikatakan rujukan yang ada dalam buku ini bersifat mutakhir. Penalaran dan penerapan saling erat kaitannya. Dimana pada proses penalaran dalam buku ini menuntut pelajar BIPA untuk berpikir kreatif dalam menuangkan ide/gagasan yang berkaitan dengan pengetahuan atau pengalaman yang pernah mereka alami. Selain itu, dengan adanya belbagai bacaan tentang sejarah kebudayaan Indonesia, para pelajar BIPA dapat menceritakan kembali kepada teman-teman setelah kembali ke negara asal. Kemenarikan materi sudah sangat baik, dengan diberikannya gambar beserta penjelasannya serta soal-soal yang mendukung KD pada bab tersebut.

Beracuan pada beberapa hasil psersentase kelayakan isi tersebut, maka persentase kelayakan isi secara keseluruhan pada buku ajar Sahabat Indonesia untuk Anak Sekolah B1 sebagai berikut.

\begin{tabular}{cc}
\hline Bab & Skor Kelayakan \\
\hline 1 & $87,5 \%$ \\
\hline 2 & $77,50 \%$ \\
\hline 3 & $75,00 \%$ \\
\hline 4 & $72,50 \%$ \\
\hline
\end{tabular}




\begin{tabular}{cc}
\hline 5 & $67,50 \%$ \\
\hline Jumlah & $380 \%$ \\
\hline Rata-Rata & $76,00 \%$ \\
\hline
\end{tabular}

Berdasarkan persentase keseluruhan dari buku tersebut maka dapat dikatakan bahwa buku ajar Sahabatku Indonesia untuk Anak Sekolah B1 layak digunakan pada kegiatan belajar mengajar dengan persentase $76,00 \%$.

\section{PENUTUP}

Berkenaan dengan hasil dan pembahasan tersebut maka buku ajar Sahabat Indonesia untuk Anak Sekolah B1 (BIPA 3) layak digunakan dalam kegiatan belajar diperguruan tinggi. Persentase kelayakannya pada buku ajar tersebut, pada bab pertama pertansenya kelayakannya sebesar $87,50 \%$, bab kedua persentasenya kelayakannya sebesar 77,50 \%, bab tiga persentasenya kelayakannya sebesar 75,00\%, bab empat persentase kelayakannya sebesar $72,50 \%$, dan, pada bab lima persentase kelayaknnya sebesar $67,50 \%$. Jadi antara bab satu sampai bab limapersentase kelayakan dalam buku ajar tersebut semakin menurun. Berdasarkan persentase kelayakan lima bab buku tersebut kelayakan isi secara keseluruhan diperoleh 76,00\%. Hal tersebut mencakup, 1) Kesesuaian Standar Kompetensi dan Kompetensi Dasar meliputi tiga indikator yaitu, kelengkapan materi, keluasan materi dan, kedalaman materi. 2) Keakuratan materi terdapat tiga indikator yaitu, akurasi prosedur, akurasi soal dan, akurasi fakta, contoh, dan isi. 3) Materi pendukung pelajar terbagi menjadi empat indikator yaitu, keterkinian fitur, contoh, dan rujukan, penalaran, penerapan dan, kemenarikan materi. Namun, akurasi soal yang diberikan kurang bervariasi antara satu bab ke bab yang lain. Penyajian materi yang terdapat dalam buku Sahabat Indonesia monoton dan kurang bervariasi. 


\section{DAFTAR PUSTAKA}

Asri, A. Sahrul. 2017. "Telaah Buku Teks Pegangan Guru dan Siswa pada Mata Pelajaran Bahasa Indonesia Kelas VII Berbasis Kurikulum 2013”. Jurnal Retorika, 3(1).

Aminudin. 1995. Pengantar Apresiasi Karya Sastra. Bandung: Sinar Baru, Algesindo.

Febriani, Meina. 2018. "Kesesuaian Materi Apresiasi Sastra Pada Buku Teks Bahasa Indonesia SMP Kurikulum 2013”. Jurnal Pendidikan Bahasa Indonesia Unissula, 6 (2).

Firdaus, Aziz, Siti Samhati, Edi Suyanto. 2014. "Analisis kelayakan Isi Buku Teks Bahasa Indonesia Terbitan Erlangga Kelas VII SMP/MTs”. Jurnal Kata, 2(4).

Khoirina, Izzatu, Suyitno, Retno Winarni. 2010. Pengenalan Budaya Indonesia Melalui Novel Ranah 3 Warnakarya A.Fuadi untuk Pemelajar BIPA. The Education Language International Conference Proceedings Center of International Language Development of Unissula.

Maesaroh, Raden. 2016. Sahabat Indonesia untuk Anak Sekolah B1. Jakarta: Kementrian Pendidikan dan Kebudayaan.

Muclish, Mansur. 2010. The Book Writting: Dasar-dasar Pemahaman, Penmulisan, dan Pemakaian Buku Teks. Yogyakarta: Ar-Ruzz Media.

Muliastutik, Liliana. 2017. Bahasa Indonesia bagi Penutur Asing. Jakarta: Pustaka Obor Indonesia.

Ratna, Nyoman Kutha. 2013. Teori, Metode, dan Teknik Penelitian Sastra. Yogyakarta: Pustaka Pelajar.

Sugiyono. 2017. Metode Penelitian Pendidikan. Bandung: Alfabeta.

Suyitno, Imam. 2007. "Pengembangan Bahan Ajar Bahasa Indonesia untuk Penutur Asing (BIPA) Berdasarkan Analisis Kebutuhan Belajar”. Jurnal Wacana, 9(1). 
Wardani, Oktarina Puspita. 2017. "Analisis Kelayakan Isi dan Bahasa Pada Buku Teks SMA "Bahasa Indonesia Ekspresi Diri dan Akademik" kelas X SMA. Jurnal Pendidikan Bahasa $\begin{array}{lllllll}\text { Indonesia } \quad \text { Unissula, } & \text { Vol } & 5 & \text { No } & \text { (2) } & \text { tahun }\end{array}$ http://jurnal.unissula.ac.id/index.php/jpbsi/article/view/2352 